\title{
Examining the Contextual Richness of Central and Eastern Europe
}

Andreja Jaklič, University of Ljubliana, Slovenia

Matevz Rasković, University of Ljubliana, Slovenia

Arnold Schuh, Vienna University of Economics and Business, Austria

\section{Introduction}

We discuss how context richness in Central and Eastern Europe (CEE) can be leveraged to further international business (IB) research and advance business practice in a new multipolar, regionalized, and increasingly "glocalized" world. We argue that CEE markets and multinational companies (MNCs) have faded to the background of existing research on emerging markets (EMs) and emerging market multinationals (EMNCs). Yet, the increasingly regional focus and specific CEE context call on IB scholars to re-examine the "CEE research stream" to provide insights on how (foreign and domestically grown) MNCs adapt their strategies in resource-constrained business environments that have undergone incredible socio-economic transitions over the last 25 years and are characterized by dynamic institutional evolution, unique transition processes, geographically compressed cultural diversity, diverse types of embeddedness, sophisticated market behaviour, and idiosyncratic innovation patterns.

\section{CEE: From Simple Geography to Context Richness}

What is CEE? Is it a region, or a common identity? Where does it begin and end? CEE is a very time- and context-specific construct transcending simple geography. It first emerged after the institutional drift and rebirth of serfdom following the Great Plague in the middle of 14 th century (1348-1350) (Acemoglu \& Robison, 2013) but became a much more prominent concept of political geography and economy after WWII and the ideological divide between West and East. Since the fall of the Berlin Wall in 1989, a mixed geographic and political view has become popular: CEE encompasses European countries which have been under socialist/communist rule and have undergone transformations from centrally-planned to market-based economies after the fall of the Iron Curtain. Thus to many, CEE countries as a region are uniquely at an intersection between advanced, emerging and developing economies (Hoskisson et al., 2013)—somehow "stuck in the middle" between West and East and between emerging transition and developed markets.

There are varying definitions of CEE. The OECD defines CEE as 12 Eastern European countries (excluding non-EU Western Balkans). UNCTAD seems to have struggled to define this region, first describing CEE as "emerging Europe," but then moving to a distinction between "developed" and "developing" Europe, with CEE countries in the latter along with CIS (Commonwealth of Independent States) countries and SouthEast Europe. Although the UNCTAD label of "developing Europe" implies an economic classification, grouping CEE with CIS countries comingles the political remnants of Soviet impact. North America sees CEE as a region dominated by a common socialist history, political ideology, adolescent democracy, and (once) absence of proper market institutions. China sees CEE within the so-called $16+1$ platform (referring to 16 countries of CEE which are or aren't EU members and China as the +1 ) where CEE is mostly a gateway for China's "One Belt, One Road" commercial and connectivity initiative. Russia, on the other hand, sees some parts of CEE in terms of its ethnic minorities and areas of cultural and historic influence. It evaluates CEE as a region in political and military terms as a "buffer zone" against NATO.

Rather than being defined internally by a common identity, CEE is in many ways defined externally in ways that aggregate economic, political, social, and geographic meanings, which reflects the region's rich context. It has been constructed in a Western discourse as being European, yet also an Eastern enigma (Wallace, 2008: 37). While it is impossible to talk of CEE in terms of a common regional identity, the ideological Iron 
Curtain and the fall of the Berlin Wall, followed by the corresponding transformation from socialist to (more or less) market economies, have nonetheless created a unique and complex common CEE identity of "newcomers" within an emerging EU of "two speeds." This has been underpinned by common feelings of historical injustice, sense of victimization, ambivalent attitudes towards "the state," as well as a mix of aspirations and disillusionment with the West.

\section{Infernationalization as the Norm for CEE Firms}

Small domestic markets and size of the region have made an international orientation in business the norm, not the exception. For example, $75 \%$ of Slovenia's GDP is driven by exports. This is twice as high as in China and almost seven times higher than in the United States. In spite of different socio-political traditions, firms in many CEE countries possess long entrepreneurial traditions preceding socialism, and a well-educated labour force. This is accompanied by strong intra-regional business relationships (CEFTA, EU), not only exemplified in trade, but increasingly in intra-regional FDIs.

Policymakers and MNCs have long viewed the complexity and heterogeneity of CEE countries as a burden and barrier to faster regional development. The global economic crises, which hit the region hard, but with a slight delay, shattered managerial assumptions of how CEE markets function and how to operate in them. More regional solutions emerged as the resulting loss of growth led many regional players to scrap investment plans, cut costs, and shift from expansion to optimization of business in the region.

While some global MNCs restructured to merge the CEE region with CIS and North Africa into one organizational division (to mitigate poor sales results), others used intensive consolidation of CEE affiliates or experimented by exploring location advantages within CEE. Managers in regional summits often agreed that "there is no rule in CEE" for optimally placing and (re)structuring production processes and sales across CEE affiliates. To date, IB research has not provided insight into this new "set of rules" for the region.

Investors in the region now pay more attention to the quality of national institutions and government performance. Also, national government attitudes toward foreign investors have changed. Governments still welcome and court investors interested in building export platforms which generate jobs and revenues, but they are more cautious toward those which focus only on their domestic market and occupy strong market positions (i.e., banks, insurances, retailers, energy producers and distributors). CEE countries such as Poland, Romania, Hungary, Slovakia, and Slovenia are still building on their industrial strength and are attracting considerable numbers of greenfield projects in manufacturing. Enhanced re-industrialization has made CEE more popular as a production and sourcing site.

FDIs have driven many changes within CEE and contributed its positioning in Europe and globally. MNC subsidiary roles vary according to headquarters (HQ) locations. The rise of Asian, Turkish, and Arabic investors in CEE that have been filling the void left by Western investors departing after the global crises have contributed to transforming CEE from a provider of geographically convenient low-wage labour to experiential laboratories at the doorstep of Europe. For example, investment motives from Chinese, Japanese, and Korean MNCs (large greenfield investors) revealed changing dynamics in location specific advantages of CEE. CEE markets increasingly offer sophisticated environments where affiliates can develop a high degree of competencies, while their small size makes them ideal testing grounds and learning laboratories for large MNCs. The 'cherry on the cake' for these foreign investors is much lower logistics costs.

\section{Consumer Demand and Innovation}

Resource constraints (budget constraints, limited natural resources, small market size, limited capital accumulation, high brain drain, etc.) drive continuous business model and market-based innovation. These result in considerable productivity upgrading and supply-side improvements. The region has many great cases of born globals and leading digital performers. The demand side is marked by price sensitive, yet demanding and sophisticated consumers, which have lower disposable incomes, but are highly cosmopolitan and similar to mainstream European customers. High levels of consumer driven innovativeness has been identified as a specific market characteristic. Different kinds of innovation, such as social innovation, efficiency, and market innovation are also strong, due to high skill levels, competencies, and capabilities, as well as a high degree of digitalization. The large degree of cultural sensitivity, extensive travel, and economically and politically-induced migration creates very high levels of cosmopolitanism among young CEE consumers. Lastly, large brain drains and diaspora communities further underpin not only consumer sophistication and resourcefulness, but also the entrepreneurial orientation and a predisposition for internationalization. While CEE may not be a strategically important market in terms of MNC profits, the potential for innovation and experimenting is huge, since it allows small-scale experimentation in a sophisticated market with high organizational competencies.

\section{The Confext of IB Teaching}

Business education in CEE countries has expanded in last two decades with a dynamic increase in the number of inter- 
national students, the emergence of private institutions, and the expansion of public academic centres. Internationalization, induced by huge intra-country and regional rivalry and a more open education space in the EU, has incentivized improvement and innovation in IB teaching and research across CEE. One area that has really acted as a catalyst has been inward student internationalization. Originally attracted by low living costs, the "different Europe" mystique, and prevalence of English, the internationalization pattern of CEE universities has been much more diverse than in the West. This has created an internationalization pattern more similar to a mosaic than a melting pot. Whereas one can find large groups of Chinese and Indian students in an international class at British, French, or German business schools, an average international class at a CEE business school has students representing up to 25 different nationalities. The immense diversity of this unique mosaic-type of inward internationalization pattern helps create a great natural environment for developing cross-cultural skills, a glocal mindset, and innovation.

\section{IB Research Opportunities in CEE}

Based on the unique context and current economic developments in CEE we believe IB scholarship in CEE should focus on three specific areas: institutional environments, differences in local and foreign firms' investment goals and strategies, and benefits of the mosaic-type internationalization. Within the institutional stream, research should focus on the positive role of institutional voids, the emerging role of economic nationalism, and the business-government relations (given large shares of state ownership and role of state-owned enterprises). The unique context of CEE may help scholars better assess if institutional differences and voids are mostly impediments for business, or under what conditions do these serve as incentives for rapid internationalization, relocation, and/or development of unique firm specific advantages (Trąpczyński \& Banalieva, 2016).

Scope and speed of changes in CEE offer opportunities for evaluating the effectiveness and impact of a specific IB policies or trade and investment promotions for business. There is also a revival of economic nationalism in CEE, seen already in a public resistance to selling state-owned enterprises to foreign firms in 1990s privatization. Such public pressure and specific interest groups seem to have affected government interventions, which have become more widespread again in recent years. Measures taken by governments in countries such as Hungary and Poland are aimed at favoring local businesses, discouraging foreign investment, and eventually re-gaining control over industries dominated by foreigners (e.g, banking, retailing, utilities).
The widely discussed topics of internationalization of local firms and, at a more advanced level, the emergence of MNCs from CEE show a major turn in perspective (Svetličič \& Jaklič, 2003). After following the market entry and expansion of foreign firms in CEE in the 1990s and early 2000s, now domestic

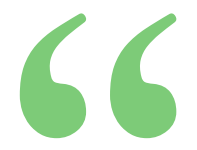

IB scholarship in CEE should focus on three specific areas: institutional environments, differences in local and foreign firms' investment goals and strategies, and benefits of the mosaic-type internationalization

firms and their internationalization patterns have become the center of attention. This environment provides an opportunity to test prevailing internationalization theories under new conditions, and to reveal if CEE firms are acting differently in terms of strategy and organization. Studies of new exporters show that they are less focused, and geographically more diversified than theory would predict (Dikova et al. 2016). Complexity of internationalization strategies goes through broader product and service portfolios, combination of different entry modes and cross-industry activity.

A particularly promising area of research is also de-internationalization and re-internationalization, of either foreign MNCs in CEE or local MNCs and born globals. Factors leading to de- and re-internationalization and differences between born globals, state-owned enterprises, and other internationalizing actors have become a prominent research topic after the global economic crisis. Particularly, a better understanding of the internationalization efforts of domestic firms is necessary as most of the outstanding export performance stems from intermediate product transfers within foreign MNC networks. Changes in subsidiary-HQ relations and the role of CEE economies within MNC networks are other topics that warrant further investigation (Schuh, 2012). Attempts to optimize regional corporate structures challenge the role of regional headquarters in guiding expansion into the region. With declining regional expansion, management has to search for synergies across the existing structures, particularly in the distribution of tasks and power among corporate, regional headquarters, and subsidiaries as well as relationships with local suppliers. Searching for synergies has also resulted in newly established regional value chains, the creation of indigenous global value chains (GVCs) 
by local firms, and their presence in multiple GVCs. In all these areas, examining CEE may yield valuable insights.

Lastly, a norm at Western journals seems to discourage scholars investigating other regions to ask "the same questions," apply the "same theories," and look at the "same phenomena" that have been examined in the West. However, this may not be a predominant view since many reviewers at these journals often do not advocate this approach. We believe a better understanding of CEE and other non-Western regions will come from exploring their rich contexts; these rich contexts allow for testing the often presumed globally applicability of theories whose replication has been limited to very similar environments. Encouraging openness in replication and in context diversity of scientific inquiry is likely to yield insights and opportunities to improve theory development.

\section{References}

Acemoglu, D. \& Robinson, A. J. 2013. Why Nations Fail: The Origins of Power, Prosperity and Poverty. London: Profile Books.

Dikova, D., Jakli , A., Burger, A. \& Kun i , A. 2016. What is beneficial for first-time SME-exporters from a transition economy: a diversified or a focused export-strategy? Journal of World Business, 51 (2): 185-199.

Hoskisson, R., Wright, M., Filatotchev, I. \& Peng, M. 2013. Emerging multinationals from mid-range economies: The influence of institutions and factor markets. Journal of Management Studies, 50(7): 1295-1321.

Schuh, A. 2012. Strategy review for Central and Eastern Europe: Strategic responses of foreign multinational corporations to the recent economic and financial crisis. Journal of East-West Business, 18(3): $1-23$.

Svetli i , M., \& Jakli , A. 2003. Outward FDI by transition economies. In: M. Svetli i \& M. Rojec (Eds), Facilitating transition by internationalization: outward direct investment from Central European economies in transition: 49-76. Burlington, VT: Ashgate.

Tr pczy ski, P., \& Banalieva, E. 2016. Institutional difference, organizational experience, and foreign affiliate performance: Evidence from Polish firms. Journal of World Business, 51 (5): 826-842.

Wallace, D. 2008. Hyperrealizing "Borat" with the Map of the European "Other", Slavic Review, 67(1): 35-49.
Andreja Jaklič (andreja.jaklii@fdv.uni-li.si) is Professor and Research Fellow at the Centre of International Relations, Faculty of Social Sciences, University of Liubliana, Slovenia, also a co-founder and board member of AIB-CEE Chapter. Her experience on internationalization, MNEs and their effects arise from academic and applied research projects, consultancy to international organizations, national agencies and business. Her work appeared in Journal of World Business, The Services Industries Journal, Transnational Corporations, Eastern European Economies, among others.

Matevz Raskovic (matevz.raskovic@ef.uni-li.si) is Assistant Professor of IB at Faculty of Economics, University of Liubljana, Slovenia. His research applies economic sociology in IB. He is a guest editor of a forthcoming special issue on business with Central and Eastern Europe in Journal of Business Research. He is assuming a new Senior Lecturer position at Victoria University of Wellington, New Zealand in February 2018.

Arnold Schuh (arnold.schuh@wu.ac.at) is Director of the Competence Center for Emerging Markets \& CEE and Assistant Professor at Vienna University of Economics and Business (WU Vienna), Austria. He is also Adjunct Associate Professor of International Business Studies at the Carlson School of Management, University of Minnesota, USA, and Honorary University Professor at Corvinus University of Budapest, Hungary. His primary research areas are marketing and strategies for CEE. 